properties of dough and its connexion with the baking quality of flour. The baking test, as such, has admittedly many disadvantages, and it is the ultimate aim of workers in this field to supplement the baking test by some other and better standard, and the Imperial Bureau of Plant Breeding and Genetics has rendered a most useful service to those engaged in this particular line of investigation by the publication of this supplement. The bibliography shows almost at a glance where further information may be obtained of what is being done in this highly important and interesting field.

\section{Predatory Birds and their Economic Status}

THE British Field Sports Society is pursuing an enlightened policy in endeavouring to educate gamekeepers and others in the identification of predatory birds and in recognizing the economic standing of each species, so that only those seriously harmful to game and other wild birds should be destroyed. In a foreword to a pamphlet of 83 pages, just published by the Society and entitled "Predatory Birds of Great Britain" (price 2s. post free), an appeal is made to gamekeepers and their employers to see that the law regarding the protection of such birds is known and enforced, and the knowledge is made easy by lists embodied in the pamphlet showing the amount of protection given in each British country to each predatory bird. The main part of the pamphlet, by Eric Parker, consists of short descriptions of the birds themselves, with illustrations by G. E. Lodge, and brief notes upon range and feeding habits. The last set out very fairly the main character of the birds' food, though we note that the little owl is condemned, contrary to the findings of the Report of the British Trust for Ornithology, that the author does not realize that the damage done by rooks depends not so much upon their numbers as upon the kind of farming where they occur, and that the blackheaded gull in Scotland is condemned on the strength of one opinion for its destruction of eggs and young birds. That is an opinion not shared on balance by Scottish county councils, which, by the way, obtain county orders from the Secretary of State for Scotland and not from the Home Secretary.

\section{Agricultural Progress}

THE current issue of Agricultural Progress (16, Pt. 1, 2s. 6d.), the official organ of the Agricultural Education Association, which is the most influential body of agricultural teachers and research workers in Great Britain, contains much interesting and instructive matter. The early days and later growth of the South-Eastern Agricultural College at Wye are described in the series dealing with the development of agricultural educational and research institutions, whilst the articles on the teaching of agriculture in schools, county instruction in farm machinery, and the educational value of tours for agricultural students, afford evidence of the real advances that are taking place at the present day on the practical side. Two particularly important topics are very fully dealt with. Mastitis disease, which causes serious losses to the milk industry, is discussed from the point of view of the veterinary surgeon, the cheesemaker and the bacteriologist. Methods of field laboratory diagnosis are explained. The other subject is afforestation, and while one author backs up his protest against the afforestation of farm land with numerous examples of the way in which the Forestry Commission has operated in Suffolk, one of the Forestry Commissioners puts forward the other side of the case. Other articles deal with such matters as the foot-rot diseases in cereals, manganese deficiency in relation to soils and crops, and the separation and analysis of soil clay fractions. A considerable space is devoted to book reviews. Agricultural Progress will in future be published twice yearly, in February and September.

\section{Higher Education in Belgium}

THE "Fondation Universitaire" was created in 1919 with funds appropriated from the final closing balance of the Commission for Relief in Belgium, of which Mr. Herbert Hoover was president. Last year Mr. Hoover accepted a joint invitation from the Fondation and the universities of Belgium to visit that country, and the occasion was marked by eloquent expressions by representatives of Belgian higher education of their sense of its indebtedness to him and to the United States and the value of the consequent cultural relations between the two countries. One of the principal functions of the Fondation is to make higher education available to poor students by means of loans, generally of 1,500 4,000 francs a year. The Fondation relies for the recovery of the loans on the sense of honour of the recipients. That this confidence is not misplaced is strikingly shown in its recently published annual report by a chart exhibiting the amounts of loans granted and refunds received from 1919 until 1938. In recent years the receipts have equalled or exceeded the grants, the annual total being in the neighbourhood of 800,000 francs. The Fondation's resources are also used for encouraging Belgian students, by means of bursaries, to study abroad, for subsidizing publications and scientific societies, for promoting international exchanges between professors and, since 1936, for the maintenance of a Bureau of University Statistics in which has been merged a commission for the study of overcrowding of the universities and unemployment of 'intellectuals'. This body has formulated recommendations for reforming the content of primary and secondary education, making more stringent the tests for promotion from one class to another, for determining what a secondary schoolleaving certificate should imply and for restricting to persons intellectually fit for them admission to institutions of university rank.

\section{The Czechoslovak Research Council}

That the leaders of science in Czechoslovakia have made every endeavour to continue scientific investigations during the past fateful year is indicated by the fifteenth annual report of their National Research Council. At the annual general meeting in March, 
Prof. B. Nømec referred to the interruption of scientific work occasioned by the country's loss of territory and institutions. Research activities were therefore upon a restricted basis though, he emphasized, it is necessary for a small nation to maintain its cultural activities at the highest possible level. $\mathrm{He}$ urged that renewed efforts be made to utilize all the country's remaining scientific institutions and resources for the continuance of all programmes of research. Dr. Ulrich, secretary of the Council, stated that donations were received from industries, corporations and private individuals so that as many students as funds permitted are being supported in the continuance of their work. Investigations in all branches of the natural sciences are still in progress at the universities and at approved institutes. This report also contains a brief account of work completed during the past year by research workers supported by the National Research Council, and the hope may be expressed that it will now continue uninterrupted by further disturbances.

\section{Medical Research in India}

SUMmaries of some of the medical research work in progress in India are contained in the annual reports of the Indian Institute for Medical Research, Calcutta, and of the Haffkine Institute, Bombay, recently issued. In the former, studies on the cholera vibrio and production and therapeutic value of an anti-cholera serum, and on an anti-typhoid serum, have been pursued. Researches on malaria and kalaazar, and the problem of a nutritional survey of Indian food-stuffs and dietaries, have also been undertaken. The Haffkine Institute is the centre for the preparation of anti-plague vaccine, of which more than thirteen million doses were issued during 1937, and work is in progress to improve the efficiency of this vaccine. A survey of the rat population of Bombay in connexion with the epidemiology of plague brings out the interesting fact that the brown and black rats, forming 70 per cent of the rat population of the city, are now highly resistant to plague, though formerly highly susceptible. In the AntiRabic Department, more than three thousand cases were treated, with a mortality of 0.08 per cent.

\section{Division of the Circle}

IN the Askania Review, the journal of the AskaniaWerke A.G. of Berlin, the well-known makers of instruments, there is an interesting and instructive article on 'The Divisions of the Circle'. It is pointed out that all topographic services of the Reich are adopting the division of the circle into 400 grades instead of 360 degrees. A history of the adoption of these units is given. The Babylonians knew that the sun completes the zodiac once within 360 days approximately, so that $1^{\circ}$ is approximately the sun's daily travel. The adoption of $360^{\circ}$ is advantageous inasmuch as the figure is readily divisible by $2,3,4,5$, $6,8,10,12$, etc. The resulting ares of the circle or the angles of $180^{\circ}, 120^{\circ}, 90^{\circ}, 72^{\circ}, 60^{\circ}, 45^{\circ}, 36^{\circ}, 30^{\circ}$, etc., are of great importance in connexion with regular diagrams as well as in technics. Since the absolute angular unit defines the angle by the ratio of the arc length to the radius, it has no 'physical' dimensions. In Germany, therefore, it is not given any special name. In other Anglo-Saxon countries it is usually called the 'radian'.

\section{Medical Supervision of University Students}

IN his inaugural thesis (Thèse de Paris, No. 136 ; 1939 ), Dr. L. Katz maintains that there is an increasing tendency in modern universities not only to provide a professional centre for students but also to supervise their mode of life, work and health, so that they can pursue their studies under the best conditions. It is in the United States that the oldest and most important university health centres have been founded, the object of which is threefold, namely : (1) to provide the students with a personal medical service including medical examination on joining, medical supervision in the course of their studies and sometimes in the treatment of illness, and medical supervision of sport ; (2) to supply all students with an elementary knowledge of hygiene; and (3) to insure a hygienic condition of the universities and the life and work of the students. In European countries a similar movement is on foot, though it has not reached the same development as in the United States. The medical centres in European universities, especially in France, confine their activities to prevention and education.

\section{The Nations and Child Welfare}

The Child Welfare Information Centre of the I seague of Nations has issued a "Summary of the Legislative and Administrative Series of Documents" received and published in 1938 (League of Nations Pamphlet, 4, 1; 1939. London: Allen and Unwin, Ltd., 1s.). This summarizes the principal administrative measures taken or enacted by Governments all over the world, and the progress made in the different countries in the sphere of maternal and child welfare, and of the training and status of social workers specializing in that sphere.

\section{Conference on Spectroscopy}

THE seventh spectroscopy conference will be held at the George Eastman Research Laboratories of the Massachusetts Institute of Technology during July 17-19. Papers and discussions on analysis of material by the emission spectrum, absorption spectrophotometry, photographic photometry, biological and chemical effects of spectral radiation, and industrial applications of spectroscopy, are being prepared. Copies of the detailed programme of the conference will be sent on request to anyone interested, but as the attendance at the conference is limited to two hundred, those expecting to attend from a distance are urged to signify in advance their intention of being present. No fee is charged. The usual summer courses on practical and applied spectroscopy will be offered at the Institute during June 12July 22. Further information can be obtained from Prof. George R. Harrison, Department of Physics, Massachusetts Institute of Technology, Cambridge, Mass. 